\title{
CORRECTION
}

\section{Correction to: A nanocomposite based on polyaniline, nickel and manganese oxides for dye removal from aqueous solutions}

\author{
L. I. Abd Ali ${ }^{1} \cdot$ Hani K. Ismail ${ }^{1} \cdot$ Hasan F. Alesary ${ }^{2} \cdot$ H. Y. Aboul-Enein ${ }^{3}$
}

Published online: 31 March 2021

(c) Islamic Azad University (IAU) 2021

\author{
Correction to: \\ International Journal of Environmental Science and \\ Technology \\ https://doi.org/10.1007/s13762-020-02961-0
}

Second author name was corrected through this correction.

Original article corrected.

The original article can be found online at https://doi.org/10.1007/

s13762-020-02961-0.

H. Y. Aboul-Enein

haboulenein@yahoo.com

1 Department of Chemistry, Faculty of Science and Health, Koya University, Koya KOY45, Kurdistan Region-F.R., Iraq

2 Department of Chemistry, College of Science, University of Kerbala, Karbala, Iraq

3 Pharmaceutical and Medicinal Chemistry Department, Pharmaceutical and Drug Industries Research Division, National Research Centre, Dokki, Cairo 12622, Egypt 